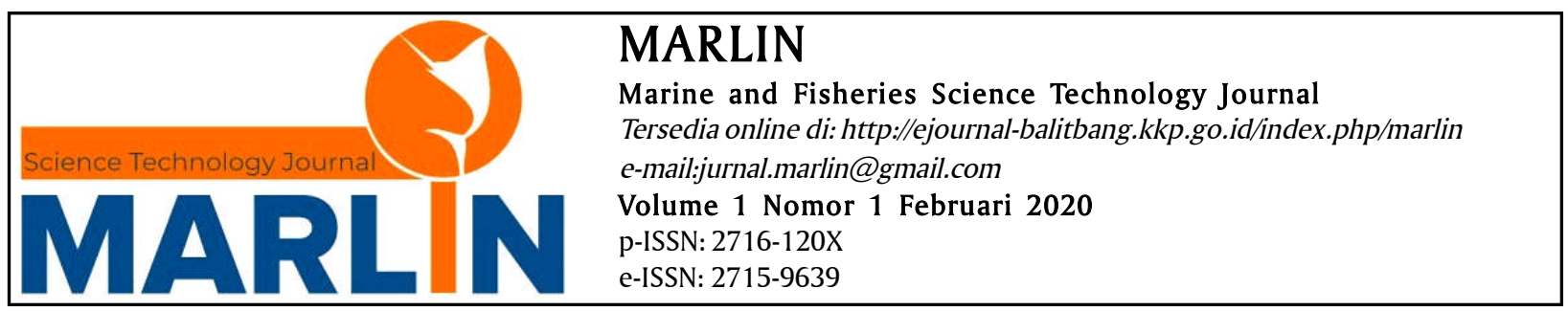

\title{
KANDUNGAN GARAM DAN KOMPOSISI PROKSIMAT IKAN ASIN JAMBAL ROTI (Arius thallassinus) DARI PANGANDARAN
}

\section{SALT CONTENT AND PROXIMATE COMPOSITION OF JAMBAL ROTI SALTED FISH (Arius thallassinus) FROM PANGANDARAN}

\author{
Deden Yusman Maulid*1 dan Satriya Abrian' \\ ${ }^{1}$ Dosen Politeknik Kelautan dan Perikanan Pangandaran, Jl. Babakan, Kec. Pangandaran, 46396, Indonesia \\ Teregistrasi I tanggal: 20 Desember 2019; Diterima setelah perbaikan tanggal: 28 Januari 2020; \\ Disetujui terbit tanggal: 28 Januari 2020
}

\begin{abstract}
ABSTRAK
Ikan asin jambal roti diproduksi dari Ikan Manyung (Arius thallassinus) dan merupakan oleh-oleh khas Pangandaran. Informasi produk ikan asin jambal roti yang dijual di Pasar Pariwisata Pangandaran sangat terbatas. Tidak ada keterangan kandungan proksimat maupun informasi kandungan kadar garam didalam kemasannya. Tujuan dari penelitian ini adalah untuk mengetahui informasi kandungan kadar garam dan komposisi proksimat pada ikan jambal roti. Kadar garam ditentukan dengan metode Mohrn sedangkan komposisi proksimat ditentukan dengan mengacu pada metode AOAC. Sampel didapatkan secara acak dari enam penjual di pasar Pariwisata Pangandaran dengan kode M1, M2, M3, M4, M5, M6. Hasil penelitian menunjukan bahwa kadar garam berkisar antara 4,75-13,17\%. Hasil pengujian proksimat menunjukan bahwa kadar air 51,55-62,45\%; kadar protein 23,6928,5\%; kadar lemak 0,38-7,08\%; kadar abu 6,57-14,27. Berdasarkan nilai SNI ikan asin 8273:2016, maka kadar garam pada sampel M3 dan M6 berada pada kisaran nilai SNI yaitu 12-20\%, dan sisanya berada dibawah nilai SNI. Hasil proksimat kadar air menunjukkan bahwa semua sampel yang dikoleksi memiliki nilai kadar air melebihi batas maksimal $40 \%$.
\end{abstract}

Kata Kunci: Angka lempeng total, jambal roti; manyung; Pangandaran; proksimat

\section{ABSTRACT}

Jambal roti salted fish was produced from giant sea catfish (Arius thallassinus) and was unique souvenir of Pangandaran. Information of jambal roti salted fish product wich is sold in Pangandaran tourism market was very restricted. There is no description about salt content and proximate composition on its package. The aim of this study was to determine the salt content and proximate composition of jambal roti salted fish. Salted content was evaluated by Mohn method, whereas proximate composition was analyzed by association of official analytical chemists method (AOAC, 2005). Samples were obtained randomly from six place in Pangandaran tourism market with code: M1; M2; M3; M4; M5; M6. The result showed that jambal roti salted fish contains 4,75\%$13,17 \%$ salt. The results of proximate composition described that the moisture 51,55-62,45\%; protein 23,6928,5\%; fat 0,38-7,08\%; and ash 6,57-14,27\%. Based on SNI of Salted fish 8273:2016, the salt contain of M3 and M6 are in the range of SNI, 12-20\%, and the remaining samples are under it range. Proximate analysis showed that all samples which were collected have a moisture value exceeding the maximum limit of $40 \%$.

Keywords: Total plate count; Jambal roti; Giant sea catfish; Pangandaran; proximate 


\section{PENDAHULUAN}

Kabupaten Pangandaran merupakan salah satu tempat tujuan wisata baik wisatawan lokal maupun mancanegara yang terletak di selatan Jawa Barat. Pangandaran sebagai tempat tujuan wisata memiliki karakteristik khas baik dari sisi lingkungan alam maupun social budaya termasuk kuliner. Salah satu ciri khas Kabupaten Pangadaran dibidang kuliner adalah Ikan Asin Jambal Roti. Ikan asin adalah ikan yang diberikan perlakuan pemberian garam dengan tujuan pengawetan dan penambah cita rasa (Margono et al., 1993). Ikan asin jambal roti merupakan ikan asin khas Pangandaran yang terbuat dari ikan manyung (Arius thallassinus). Ikan asin jambal roti di Pangandaran biasanya diproduksi secara tradisional. Pengolahan tradisional memiliki ciri peralatan yang digunakan sederhana, pengetahuan terbatas dengan keterampilan didapatkan secara turun temurun, akses modal terbatas, sanitasi dan higienis unit produksi kurang diperhatikan, dan pemasaran bersifat lokal (Dirjen Perikanan Tangkap, 2001). Wisatawan yang berkunjung ke Pangandaran sering menjadikan ikan jambal roti sebagai cindramata sehingga permintaan akan ikan asin jambal roti tinggi dan bersifat kontinyu. Produksi ikan asin dapat meningkatkan pendapatan pelaku usaha.

Permintaan yang tinggi terhadap ikan asin jambal roti dan pengetahuan yang terbatas menyebabkan produsen/ penjual menjual ikan ini tidak ada upaya lebih untuk memberikan informasi yang lengkap seperti kandungan gizi/ komposisi proksimat kandungan garamnya. Komposisi proksimat terdiri dari kadar air, protein, lemak, dan abu. Informasi tentang komposisi proksimat dan tingkat kesegaran ikan merupakan hak konsumen yang tidak boleh diabaikan. Tingkat kesegaran ikan tergantung dari perlakuan dan lama penyimpanan (Lestari et al., 2015). Penambahan garam pada ikan dapat menyebabkan ikan tersebut awet dan memiliki penambahan rasa asin. Namun, apabila penambahan garam pada ikan berlebihan, dapat menyebabkan terganggunya rasa dan terganggunya kesehatan karena dapat menyebabkan darah tinggi (Polii et al., 2016). Tekanan darah biasanya dipicu oleh tekanan plasma. Asupan natrium dapat menyebabkan bertambahnya tekanan plasma sehingga secara tidak langsung asupan natrium pada garam yang dikonsumsi dapat menyebakan meningkatnya tekanan darah (Anggara et al., 2012). Informasi mengenai kandungan garam ini menjadi penting karena berhubungan dengan keamanan dan kenyamanan konsumen dalam mengkonsumsi makanan khususnya ikan asin jambal roti yang sudah menjadi makanan favorit bagi wisatawan yang berkunjung ke Pangandaran. Namun berdasarkan observasi langsung yang dilakukan oleh peneliti, tidak ada informasi yang memadai yang didapatkan didalam kemasan ikan asing jambal roti baik itu informasi mengenai kadar garam ataupun komposisi proksimat.

\section{BAHAN DAN METODE}

Bahan yang digunakan pada penelitian ini adalah ikan jambal roti ikan manyung yang dikoleksi dari enam (6) tempat berbeda di sekitar Pasar Wisata Pangandaran. Bahan analis yang digunakan diantaranya adalah: $\mathrm{H}_{2} \mathrm{SO}_{4}$ pa, $\mathrm{NaOH} 30 \%, \mathrm{H}_{3} \mathrm{BO}_{3} 3 \%, \mathrm{HCl} 0,1 \mathrm{M}$, larutan bromcresol green, akuades, hexane, $\mathrm{HCl} 6 \mathrm{~N}$, Metanol, aseton, n-Oktil alcohol, kalium borat, $\mathrm{AgNO}_{3}, \mathrm{~K}_{2} \mathrm{CrO}_{4}$ (merck).

\section{Kadar Garam}

Pengujian kadar garam dihitung dianalisis dengan metode Mohr. Sample ditimbang sebanyak 2 gr kemudian dilarutkan dalam akuades $100 \mathrm{ml}$. diambil sebanyak $10 \mathrm{ml}$ kemudian dititrasi dg $\mathrm{AgNO}_{3} 0,1 \mathrm{~N}$ dan indicator $\mathrm{K}_{2} \mathrm{CrO}_{4}$ $5 \%$. Penentuan kadar garam dihitung dengan rumus:

Kadar garam $=\frac{\mathrm{ml} \text { sampel } \times \mathrm{N} \text { AgNO3 } \times 0,05844 \times \mathrm{fk} \times \text { x } 100 \%}{\text { Berat sample }}$.(1)

\section{Komposisi Proksimat}

Pengujian kadar proksimat terdiri dari Analisis kadar air, kadar abu, kadar, lemak dan kadar protein. Analisis kadar air dihitung menggunakan metode Gravimetri (AOAC, 2005) dimana penentuan kadar air berdasarkan rumus sebagai berikut:

Kadar air $(\%)=\frac{\text { B - C }}{\text { B - A }} X 100 \%$

Keterangan:

A : berat cawan kosong (gr)

$\mathrm{B}$ : berat cawan + sampel awal (gr)

C: Berat cawan + sampel kering (gr)

Kadar abu dilakukan menggunakan metode oven (AOAC, 2005). Penentuan kadar abu dihitung berdasarkan rumus sebagai berikut:

Kadar abu $(\%)=\frac{\mathrm{C}-\mathrm{A}}{\mathrm{B}-\mathrm{A}} X 100 \%$

Keterangan:

A : berat cawan kosong (gr)

$\mathrm{B}$ : berat cawan + sampel awal $(\mathrm{gr})$

$\mathrm{C}$ : berat cawan + sampel kering $(\mathrm{gr})$

Kadar lemak dilakukan dengan metode sokhlet (AOAC, 2005). Penentuan kadar lemak dihitung berdasarkan rumus sebagai berikut:

Lemak total $(\%)=\frac{\mathrm{C}-\mathrm{A}}{\mathrm{B}} X 100 \%$

Keterangan:

A : berat labu alas bulat kosong (gr)

B : berat sampel (gr)

C : berat labu alas bulat dan lemak hasil ekstraksi (gr) 
Kadar protein dilakukan dengan metode kjeldahl (AOAC, 2005). Penentuan kadar protein dihitung berdasarkan rumus sebagai berikut:

$$
\text { Protein }(\%)=\frac{(\mathrm{VA}-\mathrm{VB}) H C L \times \mathrm{N} \text { HCL } \times 14,007 \times 6,25}{\mathrm{Wx} 1000}
$$

Keterangan:

VA : $\quad \mathrm{ml} \mathrm{HCl} \mathrm{untuk} \mathrm{titrasi} \mathrm{sampel}$

$\mathrm{VB}$ : $\mathrm{ml} \mathrm{HCl} \mathrm{untuk} \mathrm{titrasi} \mathrm{blanko}$

$\mathrm{N}$ : normalitas $\mathrm{HCl}$ standard yang digunakan14,007: berat atom Nitrogen 6,25: factor konversi protein untuk ikan

$\mathrm{W}$ : berat sampel (gr)

\section{HASIL DAN BAHASAN}

Hasil

Titrasi argentometrik digunakan untuk menentukan kadar garam pada sampel ikan asin jambal roti yang dikoleksi dari pasar wisata Pangandaran. Hasil analisis kadar garam dapat dilihat pada tabel 1 .

Berdasarkan data yang ditampilkan pada tabel diatas, nilai kadar garam dari sampel yang dikoleksi berkisar antara 4,76-13,17\%. Nilai paling tinggi terdapat pada sampel M6 $(13,17 \%)$ sedangkan nilai kadar garam terendah terdapat pada sampel M5 (4,76\%). Sampel yang memiliki Kadar garam yang berada pada kisaran nilai yang ditetapkan oleh SNI (12-20\%) adalah sampel M3 (12,07\%) dan M6 (13,17\%). Sampel lainnya yakni M1; M2; M4; M5 memiliki nilai dibawah kisaran yang sudah ditetapkan oleh SNI. Perbedaan kadar garam bisa disebabkan oleh perbedaan metode produksi terutama pada saat proses penggaraman (Suharna et al., 2006). Pada umumnya proses pembuatan ikan asin jambal roti adalah seperti ditampilkan pada gambar 1 .

Tabel 1. Hasil Uji Kadar garam Ikan Jambal Roti

\begin{tabular}{cccc}
\hline No & Kode Sampel & Kadar garam (\%) & SNI 8273:2016 \\
\hline 1 & M1 & 11,25 & \\
2 & M2 & 5,48 & \\
3 & M3 & 12,07 & $12-20 \%$ \\
4 & M4 & 10,95 & \\
5 & M5 & 4,76 & \\
6 & M6 & 13,17 & \\
7 & Ikan Asin kambing-kambing & 12,84 & \\
\hline
\end{tabular}

a) (akbardiansyah et al., 2018)

Tahapan proses yang menentukan kadar garam terdapat pada proses pemberian garam (langkah ke 4) dan pencucian 2 (langkah ke 6). Pada saat proses pemberian garam (penggaraman), jumlah garam yang diberikan (konsentrasi garam) dan lamanya (waktu) proses penggaraman sangat mempengaruhi kadar garam pada ikan asin jambal roti. Semakin tinggi konsentrasi garam yang diberikan serta semakin lama proses penggaraman maka kandungan garam pada produk akan semakin tinggi begitu pula sebaliknya semakin kecil konsentrasi garam dan semakin sedikit waktu penggaraman, maka kandungan garam pada ikan jambal roti semakin kecil. Proses pencucian (pencucian 2) juga sangat berpengaruh terhadap kadar garam yang dihasilkan. Pencucian dapat menurunkan kadar garam pada ikan jambal roti karena garam yang terdapat pada ikan jambal roti dapat larut dan terbawa oleh air cucian. Akabardiansyah et al. (2018) melaporkan bahwa Terjadi pola penurunan kadar garam pada ikan asin seiring dengan diturunkanya konsentrasi garam pada proses penggaraman.

Hasil pengujian proksimat mengukur kadar air, protein, lemak, dan abu. Semua sampel ikan asin jambal roti yang didapatkan dari Pasar Wisata Pangandaran menunjukan bahwa terdapat perbedaan kadar air, kadar protein, kadar lemak, dan kadar abu bila dibandingkan dengan kadar proksimat ikan manyung seperti ditampilkan pada table 2 . 


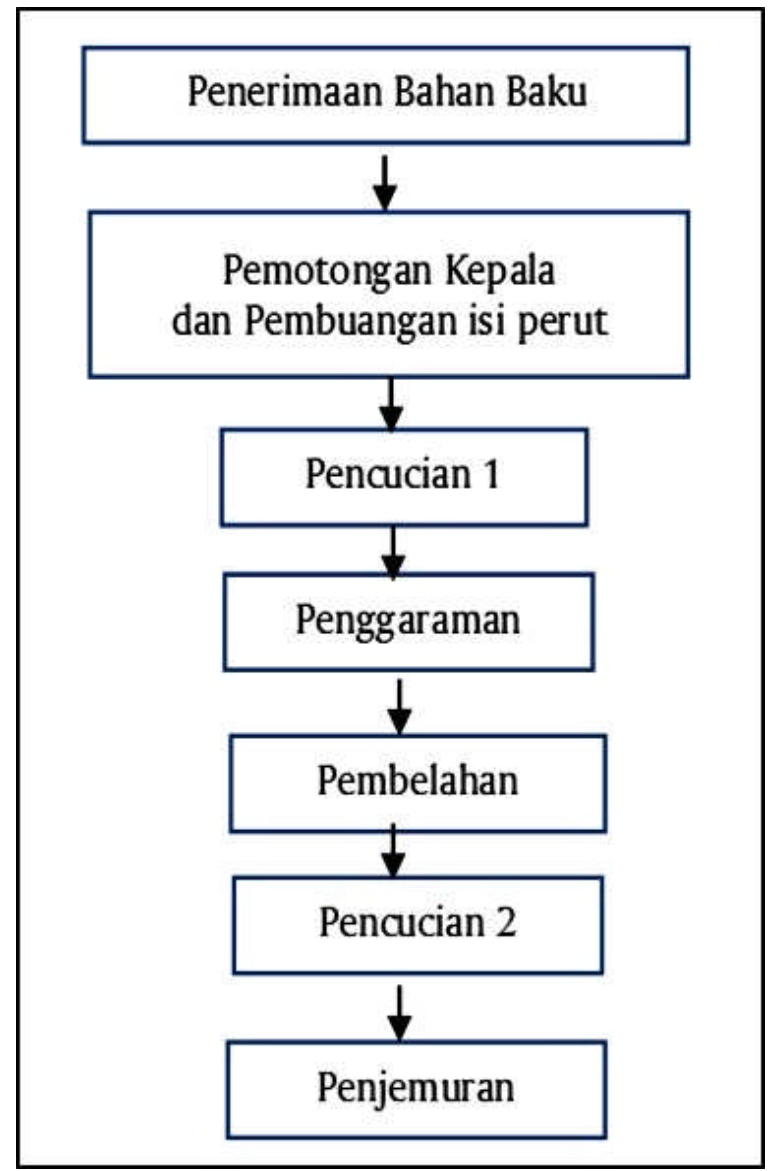

Gambar 1. Proses Pembuatan Ikan Jambal Roti.

Tabel 2. Hasil Uji Proksimat Ikan Asin

\begin{tabular}{cccccc}
\hline No & Kode sampel & Kadar Air (\%) & Protein (\%) & Lemak (\%) & Abu (\%) \\
\hline 1 & M1 & 55,38 & 28,5 & 2,22 & 10,01 \\
2 & M2 & 57,18 & 27,96 & 6,9 & 6,92 \\
3 & M3 & 50,44 & 23,23 & 6,73 & 13,55 \\
4 & M4 & 54,93 & 26,26 & 2,71 & 13,47 \\
5 & M5 & 58,45 & 26,61 & 3,8 & 6,57 \\
6 & M6 & 51,92 & 23,53 & 7,08 & 14,27 \\
7 & Ikan manyung) & 79,15 & 18,56 & 0,54 & 1,79 \\
\hline
\end{tabular}

(Abraham et al., 2017)

Berdasarkan Tabel 1 diatas, hasil analisis proksimat semua sampel untuk kadar air berkisar antara 50,44-58,45\% dengan nilai tertinggi didapatkan dari hasil pengujian sampel M5 dan nilai terendah sampel M3. Hasil kadar protein berkisar antaran 23,23-28,5\% dengan nilai tertinggi didapatkan dari hasil pengujian sampel M1 dan hasil terendah sampel M6. Hasil kadar lemak berkisar antara 2,22-7,08\% dengan hasil tertinggi didapatkan dari hasil pengujian sampel M6 dan nilai terendah sampel M1. Hasil kadar abu berkisar Antara 6,57-14,27\% dengan nilai tertinggi didpatkan dari hasil pengujian sampel M6 dan nilai terendah dari sampel M5.

Semua sampel menunjukkan nilai kadar air yang lebih rendah bila dibandingkan dengan hasil uji pada ikan manyung $(79,15 \%)$. Hal ini disebabkan oleh penambahan garam pada saat proses pembuatan ikan asin jambal roti. Garam menyebabkan air yang terkandung dalam tubuh ikan tertarik keluar. Garam memiliki sifat yang dapat menarik air dari system ke lingkungan. Hasil kadar air semua sampel menunjukan diatas nilai SNI ikan asin 8273:2016 (40\%). Hal ini disebabkan karena ikan jambal roti yang dikoleksi di pasar wisata pangandaran disimpan dalam keadaan lembab di dalam freezer, sehingga kandungan air pada ikan asin jambal roti masih tinggi. Kadar air merupakan air bebas yang terikat secara fisik dalam jaringan matriks bahan seperti matriks dan kapiler (Winarno, 2008). Kadar air juga dapat digunakan sebagai indicator untuk menunjukan jumlah relative energy (Dempson et al., 2004). Paparang (2013) melaporkan 
bahwa terjadi penurunan kadar air seiring dengan meningkatnya kadar garam yang digunakan. Selain nilai konsentrasi, penurunan kadar air juga dipengaruhi oleh lamanya penambahan garam (Rahmani et al., 2007).

Protein merupakan komposisi terbesar setelah setelah kadar air. Hasil pengujian kadar protein menunjukkan bahwa semua sampel memiliki nili yang lebih tinggi bila dibandingkan dengan nilai kadar protin ikan manyung $(18,56 \%)$. Peningkatan persentase kadar protein disebabkan berkurangnya kadar air yang diakibatkan oleh penambahan garam pada proses pengolahan ikan asin jambal roti. Kehilangan air menyebabkan perubahan persentase komposisi proksimat. Ikan manyung termasuk ikan yang memiliki kadar protein tinggi. Ikan yang memiliki kadar protein lebih dari 15\% dikategorikan ikan berprotein tinggi (Njinkoue et al., 2016). Komposisi protein bisa dijadikan sebagai acuan kualitas ikan. Semakin tinggi kadar protein semakin baik ikan tersebut karena memiliki zat pembangun tubuh yang lebih banyak (Abraham et al., 2012).

Hasil analisis kadar lemak menunjukan bahwa semua sampel yang diuji memiliki nilai diatas kadar lemak ikaan manyung $(0,54 \%)$. Kenaikan nilai kadar lemak sama halnya dengan kenaikan kadar protein yakni disebabkan oleh berkurangnya kadar air yang diakibatkan oleh penambahan garam pada proses pengolahan ikan jambal roti. Ikan manyung termasuk ikan yang memiliki kadar lemak yang rendah. Kandungan lemak ikan berlemak rendah berada dibawah 3\%. Sedangkan ikan berlemak sedang sekitar 3-5\%. Ikan yang dikategorikan sebagai ikan berlemak tinggi memiliki kadar lemak diatas 5\% (Venugoval, 2008).

Kadar abu merupakan campuran mineral dengan komponen anorganik yang terdapat dalam suatu bahan pangan yang tidak terbakar pada proses pembakaran bahan organic (Winarno, 2008). Berdasarkan tabel 1, hasil analisis kadar abu menunjukkan bahwa semua sampel yang diuji memiliki nilai diatas ikan manyung $(1,79 \%)$. Hal ini disebabkan oleh penambahan garam pada proses pengolahan ikan asin jambal roti. Garam mengandung makromineral yaitu Natrium. Penambahan garam pada proses pengolahan ikan jambal roti bisa diartikan menambah mineral ( $\mathrm{Na}$ ) ke dalam tubuh ikan yang diasinkan. Sehingga kadar abu pada semua sampel jauh diatas ikan manyung sebagai bahan baku pembuatan ikan asin jambal roti. Salamah et al. (2012) menyatakan bahwa perlakuan penambahan garam pada remis dapat meningkatkan kandungan makromineral (Na). Penelitian lain melaporkan bahwa kadar abu udang Pneaus semisulcatus meningkat setelah dilakukan perebusan garam $(9,4 \%)$ (Unlusyn et al., 2010).

\section{KESIMPULAN}

Kadar garam ikan asin jambal roti yang berasal dari Pasar Wisata Pangandaran berkisar antara 4,76-13,17\%. Komposisi proksimat ikan asin jambal roti menunjukan bahwa kadar air 51,55-62,45\%; kadar protein 23,6928,5\%; kadar lemak 0,38-7,08\%; kadar abu 6,57-14,27. Berdasarkan nilai SNI ikan asin 8273:2016, maka kadar garam pada sampel M3 dan M6 berada pada kisaran nilai SNI yaitu $12-20 \%$, dan sisanya berada dibawah nilai SNI. Hasil proksimat kadar air menunjukkan bahwa semua sampel yang dikoleksi memiliki nilai kadar air melebihi batas maksimal $40 \%$.

\section{PERSANTUNAN}

Kami mengucapkan terima kasih kepada Direktur Politeknik KP Pangandaran yang sudah mendukung selama kegiatan penelitian dan penulisan naskah.

\section{DAFTAR PUSTAKA}

Abraham, B., Mahmud, A., Samuel, M., Yhdego, W., Kibrom, S., \& Habtom, W. (2017). Production of fish protein hydrolysate from silver catfish (Arius thallasinus). MOJ Food processing and technology. 5 (4), 1-8.

Abraham, O., Adejonuwo, A.O., Cramedike., \& Kolade, (2012). Proximate composition of P elongates subjected to different processing techniques. Journal fish aquatic science. 8 (1), 282-286.

Akbardiansyah., Desniar., \& Uju., (2018). Karakteristik ikan asin kambing-kambing (Chantidhermis maculate) dengan penggaraman kering. JPHP, 21(1), 345-355.

Anggara, F., \& Prayitno, N. (2012). Faktor-faktor yang berhubungan dengan tekanan darah di puskesmas telaga murni Cikarang barat. Jurnal ilmu kesehatan. 5(1), 1-7.

AOAC, (2005). Official Methods of Analysis. Association of Official Analytical Chemists. Benjamin Franklin Station, Washington.

Dempson, I.B., Schwarj, C.J., Shear, M., \& Furey, G. (2004). Comparative proximate body composition of atlantic salmonwith emphasis on parr from fluvial and lacustrine habitats. Journal of fish biology. 64(1), 1257-1271.

Direktorat Jenderal Perikanan Tangkap. (2001). Inventarisasi Jenis dan Jumlah Produk Olahan Hasil Perikanan Skala Kecil di Indonesia. Jakarta. 
Lestari, N., Yuwana., \& Efendi, Z. (2015). Identifikasi tingkat kesegaran dan kerusakan fisik ikan di pasar minggu kota Bengkulu. Jurnal Agroindustri. 5(1), 44-56.

Margono, T., Suryati, D., Hartinah, S. (1993). Teknologi pangan. Jakarta: Pusat Informasi Wanita dalam pembangunan.

Njinkoue, J.M., Gouado, I., Tchoumbougnang, F., Ngueguim, J.H., Ndinteh, D.T, Fomognefodjo., \& Schwigert, F.J, (2016). Proximate composition, mineral content and fatty acid profile of two marine fish from Cameroonian coast:Pseudotolithus typus, and Pseudolithus elongitus. NFS Journal. 4(1), 27-31.

Paparang, R.W. (2013). Studi pengaruh variasi konsentrasi garamterhadap citarasa ikan layang. Jurnal media teknologi hasil perikanan. 1(1), 1-4.

Polii, R., Engka, J.N.A., \& Sapulete, I.M. (2016). Hubungan kadar natrium dengan tekanan darah pada remaja di kecamatan bolongitang barat kabupaten bolang mongondow utara. Journal e-biomedik. 4(2), 1-7.

Rahmani, Y., \& Erryana, M. (2007). Pengaruh metode penggaraman basah terhadap karakteristik produk ikan asin gabus (Ophiocephalus stratus). Jurnal teknologi pertanian. 8(3), 142-152.
Salamah, E., Purwaningsih, S., \& Kurnia, R. (2012). Kandungan mineral remis (Corbicula javanica) akibat proses pengolahan. Jurnal akuatika, 3(1), 74-83.

Sukmawati, Ratna, Fahrizal. (2018). Analisis cemaran mikroba pada daging ayam broiler di Kota Makassar. Jurnal Scripta Biologica, 5(1), 68-71.

Suharna, C., Sya'rani, L., \& Agustini, T.W. (2006). Kajian system manajemen mutu pada pengolahan ikan jambal roti di Pangandaran, Kabupaten Ciamis. J.Pasir laut, 2(1), 13-25.

Unlusyn, M., Erdilal, R., Gumus, B. (2010). The effect of salt boiling on protein loss of Pneaus semisulcatus. Turksih journal of fisheries and aquatic science. 10(1), 75-79.

Venugoval, (2008). Seafood processing; adding value through quick freezing retortable packaging and cook chilling. New York (US): Taylor and Franch publisher.

Winarno, F.G. (2008). Kimia Pangan dan Gizi.Jakarta (ID). Gramedia Pustaka Utama. 